\title{
An Information and Marketing System for Agrocomplex Sector Based on Reliable Digital Technology as a Supporting Capacity for Food Security in a Force Majeure Event
}

Endang Sulistyaningsih ${ }^{1 *}$, Valentina Dwi Suci Handayani ${ }^{1}$, Widiastuti Setyaningsih ${ }^{2}$, Wahdan Fitriya $^{3}$, Arif Wahyu Widada ${ }^{4}$, Candra Aryudiawan ${ }^{3}$, Taufan Alam $^{1}$, Imas Masithoh Devangsari $^{5}$

${ }^{1}$ Departement of Agronomy, Faculty of Agriculture, Universitas Gadjah Mada, Yogyakarta, Indonesia ${ }^{2}$ Departement of Food and Agricultural Product Technology, Faculty of Agricultural Technology, Universitas Gadjah Mada, Yogyakarta, Indonesia

${ }^{3}$ Department of Fisheries, Faculty of Agriculture, Universitas Gadjah Mada, Yogyakarta, Indonesia ${ }^{4}$ Departement of Agricultural Socio-Economics, Faculty of Agriculture, Universitas Gadjah Mada, Yogyakarta, Indonesia

${ }^{5}$ Departemen of Soil Science, Faculty of Agriculture, Universitas Gadjah Mada, Yogyakarta, Indonesia

Submitted: December 28 ${ }^{\text {th }}$ 2020; Revised: August $4^{\text {th }}$ 2021; Accepted: September $3^{\text {rd }} 2021$

Keywords:
Digital
applications
Food security
Information
system
Marketing
system

\begin{abstract}
The pandemic situation experienced by the world is currently threatening food security in various regions including Indonesia. As a strategic step to reduce the impact on the agricultural sector, it is necessary to accelerate information to support the stability of production and also to distribute production results. Digital media in agriculture are needed to provide education with a variety of contents, such as technical production, marketing, and agricultural finance information. The Faculty of Agriculture of Universitas Gadjah Mada (UGM) has supported digital information dissemination through the Desa Apps application. Desa Apps aims to be an application platform that provides agricultural extension and develops digital farmer communities. The information that has been carried out by Desa Apps so far includes agrocomplex sector (agriculture, animal husbandry, and fisheries) problems related to cultivation methods and obstacles faced in the land such as attack by plant pest and disease. As a digital media, the Desa Apps has educated farmers and aquaculturists. This study evaluates whether farmers and aquaculturists under the auspices of the Faculty of Agriculture are interested in being able to get an education and at the same time be able to market their product directly to consumers with one application, the Desa Apps. The findings of the study showed that the pandemic period greatly affected the incomes of the assisted target community, and they required media that can help market their product. The decline in turnover due to pandemic conditions reached $70 \%$ with an average decrease of $39.2 \%$. The method of selling products has changed from conventional to online sales by $20 \%$ of the total respondents. Changes in sales methods occurred due to distribution limitations due to regional and activity restrictions during the pandemic. Therefore, it is necessary to optimize theDesa Apps application as a digital media to support food security.
\end{abstract}

\section{INTRODUCTION}

The COVID-19 pandemic has been present in almost all countries in the world, including Indonesia. The impact of the pandemic has affected the stability of various sectors (Supriyanto, 2020). Agrocomplex sector (a griculture, animal husbandry, and fisheries) is one of the crucial sectors that has also been affected. This impact has caused the stagnation of traffic flows in the Agrocomplex sector from production facilities

ISSN 2460-9447 (print), ISSN 2541-5883 (online)

${ }^{*}$ Corresponding author: Sulistyaningsih

Departement of Agronomy, Faculty of Agriculture, Universitas Gadjah Mada, JL Flora, Bulaksumur, Karang Malang, Caturtunggal, Depok, Sleman 55281, Daerah Istimewa Yogyakarta, Indonesia

Email: endangsih@ugm.ac.id 
until the distribution of harvested crops and products, and it is due to socia lrestrictions in various parts of the country (Ridhoi, 2020). It can affect the food availability for the community and the national food security.

Strategic steps arenecessary to reduce this impact on the a grocomplex sector. One of the steps required is accelerating information to support production stability and a lso distribution of production results. The faculty of Agriculture of UGM has supported the dissemination of information about technological innovations in the a grocomplex sector digitally through an Android-based mobile application. Digital Extension Society for Agriculture Application otherwise known as 'Desa apps' has become an application (a platform) that provides a gricultural extension and develops digital farmers and aquaculturist communities (Raya et al., 2018). Desa Apps is a communication medium between farmers, communities, and agricultural experts. Communication that has been carried out through the Desa Apps application so far includes agricultural problems related to cultivation methods and obstacles encountered in the field such as pest a ttacks or disease occurrences. This application a lso has a market feature that facilita tes buying and selling products. However, market features have not maximized the marketing of agrocomplex products and information related to the facilities that support agrocomplex production.

Digital media in a griculture is needed to educate farmers with various contents such as technical production, marketing, and information on agricultural financing (Subejo et al., 2018). The importance of online marketing development is based on the growth of the number of the internet user (Schwarzl and Grabowska, 2015). The Desa Apps application has educated the public a lot about agriculture, animal husbandry, and fisheries. This application has been downloaded by more than 1000 users spread throughout Indonesia. This is an opportunity to optimize the Desa Apps application as a medium that can support food security during any force majeure event, not only limited to the COVID-19 pandemic. This study was conducted to obtain feedback from users to optimize the use of the Desa Apps application as an information, education, and marketing system for agrocomplex sector to support food a vailability for the community and national food security during force majeure events.

\section{METHOD}

This study was conducted by surveying 100 respondents from farmer groups assisted by the Faculty of Agriculture of UGM. These groups consisted of Merbabu farmer group, Ngablak, Magelang; Mina Kepis a quaculturists group, Sumberadi, Sleman; Pawon Gendis farmer women's group, Kalibawang, Kulon
Progo, dan Ngudi Mulyo farmer group, Sapen, Manisrenggo, Klaten The activities were carried out from July to December 2020. This study aimed to get feedback from the users of the Desa Apps application as a reliable system to support food security during the force majeure event. The Desa Apps application can be downloaded from Google Play Store and used for free. Users only need to download, install the application, and register, after which they can take advantage of the features available in the Desa Apps application.

The stages of this activity stages included preparation, program planning, information dissemination, the implementation of activities, monitoring, and evaluation. The followings are the details of each stage:

1. Preparation consisted of collecting initial information about the respondents' loca tion, type of cultivation, potential production results, and the respondent's use of the Desa Apps a pplica tion.

2. Activity planning was the preparation of a plan or design for the use of the Desa Apps a pplication.

3. Information dissemination was conveying the purpose and objectives of the activity and making an initial agreement for the follow-up plan to be carried out.

4. The implementation of activities has been camied out by the group with assistance from the researchers, extension workers, and community lea ders through the Desa Apps application.

5. Monitoring and Evaluation were carried out to determine the progress of the implementation of activities and assess the suitability of the activities that had been carried out following the planning. This activity was a lso a means of disseminating information related to the Desa Apps application and its utilization. The objective of this activity was to gain feedback from users as a basis for developing applications so that they can become reliable digital media as supporting ca pacities for food security during force majeure events.

\section{RESULT AND DISSCUSSION}

\subsection{General information of farmers and aquaculturists respondents}
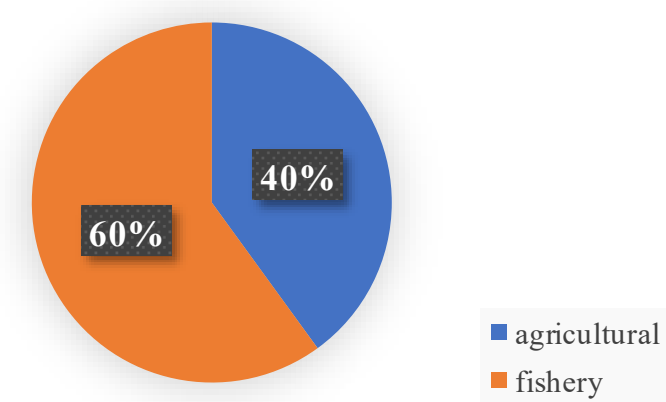

Figure 1. Diagram of the composition of the respondents in the agricultural and fishery sectors 
The data from the survey of 100 respondents were divided into $60 \%$ or 60 respondents running their businesses in the agricultural sector and $40 \%$ or 40 respondents running their businesses in the fishery sector. The data on the composition of the respondents are shown in Figure 1.

\subsection{Product potential}

The results of data collection from the respondents are potential for the products produced, including staple food products, vegetables, and fruit. The data show that $30 \%$ of the 60 respondents in the agricultural sector cultivate staple food crops such as rice and corn; 30\% cultivate vegetable-producing crops; $20 \%$ cultivate fruit-producing plants; $20 \%$ cultivate staple food crops and vegetable-producing crops, and $10 \%$ cultivate staple food crops and fruitproducing crops. There were no farmers who cultivated a combination of vegetable and fruit crops. This shows that the cultivation of staple food crops is still very popular among farmers because of the guarantee of consumer certainty and the stability of staple food prices. The prices of staple foods are more stable than those of vegetable and fruit products. During the harvest season or when there are abundan tharvests, the price of vegetables and fruit may experience a decline at the fam level to more than $50 \%$ of the average price. This causes farmers to tend to take safe steps to cultivate staple food crops. On the other hand, some farmers focus on cultivating only vegetables or fruit with considerations of efficiency in its management related to labor costs to manage which crops are quite expensive when they cultivate various crops. Efforts to minimize the costs covered in the production process are made by the farmers by choosing the types of vegetables or fruit commodity based on predictions of the price when they are harvested. Therefore, pricingrelated information is needed by farmers to predict the price before the harvest. a

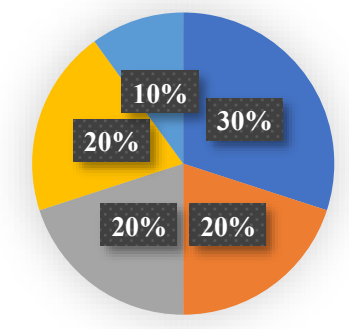

b

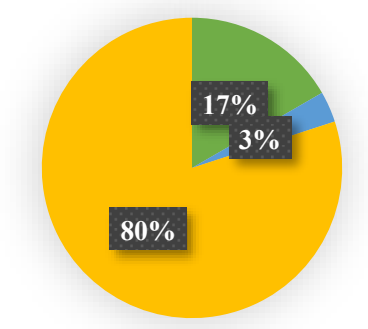

- Staple Food

- Vegetables

Fruits

Staple Food dan

Vegetables

- Staple Food dan Fruits

\section{Fish hatchery}

Fish Segmentation

Fish consumption
Figure 2. Products' potentials: a) agricultural; b) fishery
Respondents who conduct business in the fisheries sector with thenumber of 40 respondents were divided into $80 \%$ of fish consumption, $17 \%$ of the fish hatchery, and $3 \%$ of fish segmentation (fish farming up to a certain size). Aquaculturists for consumption are in great demand even though the time required and risk are greater than the hatchery and segmentation. This is because the selling price of incoming consumption is higher and is considered quite profitable. The composition of potential agricultural and fishery products based on the respondents are shown in Figure 2.

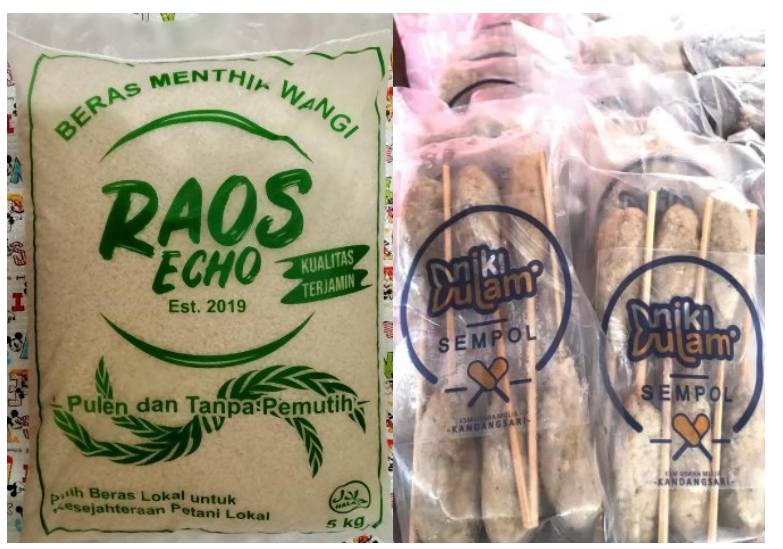

Figure 3. Examples of products with safe packaging that are ready to be marketed

Agricultural and fishery products produced by the a ssisted groups of the UGM's Faculty of Agriculture are not only fresh products but also attractively packaged and partially processed products to increase their selling values. Processing and packaging are a ttractive and safe when the products are shipped sothat this becomes an opportunity for the distribution or marketing of products to more distant areas. The a vailability of products that can be sent to remote areas makes the need for applications that facilitate distribution become urgently needed. Examples of products that are packaged sa fely and attractively are shown in Figure 3.

\subsection{The pandemic's impacts}

The pandemic that has been present up until today has raised a concern that there will be food shortages as a result of the restriction situation in various regions. The impact of territorial restrictions has hampered the sa le of agricultural and fishery products despite some a gricultural and fishery products ca nnot be stored for a long time and in large quantities. The distribution must be done immediately so that the quality of the product does not decrease. However, regional restrictions lead to food shortages in areas with consumer dominance and product accumulation in the producing a reas. This causes prices in producing a reas to be very low, and eventually, some products a re wasted. The impact of 
territorial restrictions caused a decrease in turnovers among the farmers and a quaculturists reaching 70\% with an average decrease of 39.2\% (Figure 4). Meanwhile, in other areas, there was a very sharp increase in prices due to limited supplies. The a vaila bility of the digitizing of the marketing system is expected to provide information on the availability of products in an area that can be obtained easily and can be distributed quickly. Digital information regarding product a vailability is expected to support equitable distribution and price stability to maintain food security.

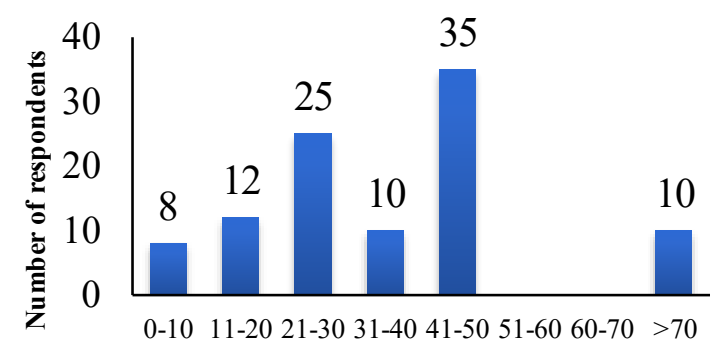

Turnover Decrease (\%)

Figure 4. Graph of variations in turnover decrease due to the pandemic

\subsection{Digital information system}

\begin{tabular}{cll} 
Table 1. Features of the desa apps application & \\
\hline No & \multicolumn{1}{c}{ Feature } & Availability \\
\hline 1 & Info waktu dan cuaca (time and & $\begin{array}{l}\text { Location } \\
\text { available }\end{array}$ \\
& weather) & $\begin{array}{l}\text { Partially } \\
\text { available }\end{array}$ \\
2 & List harga pangan (price list) & Available \\
3 & List tanya jawab (Q/A list) & Available \\
4 & List/detail artikel (article list) & Available \\
5 & Tampilan info cuaca (weather display) & Available \\
6 & List Toko (store list) & Available \\
7 & List Kantor (office list) & Available \\
8 & List Catatan Tani (farmer note list) & Available \\
9 & List Komoditas (commodity list) & Available \\
10 & Detail profil (profile details) & Available \\
11 & List ranking (ranking list) & Available \\
12 & List notifikasi (notification list) & Available \\
13 & List kotak masuk (inbox list) & Available \\
14 & List survey (survey list) & Available \\
15 & List Catatan Tani Saya (my farmer & \\
& note list) & Available \\
16 & Info developer (developer & information) \\
\hline
\end{tabular}

As a digital application media, the Desa Apps application has a variety of features that are expected to support the information system needed by its users. Table 1 shows 16 features offered by the Desa Apps, and all of these features have good information availability. The food pricing info feature can be a good ba sis to determine the producer price of a product one wishes to offer. In addition, there is also a price info fea ture that helps consumers to get the right price range. Another thing that is no less interesting than other features offered by the Desa Apps is the question-andanswer feature. In the question-and-answer feature, users can have thorough discussions with experts in their fields, agricultural extension centers, fellow fa rmers, and aquaculturists regarding the obstacles they face during the cultivation process. These discussions help farmers and a quaculturists in getting information and fast solutions to the problems they face. The Desa Apps has developed featuresneeded by users to provide fa st and reliable information. The information provided through the Desa Apps application is accurate, officially obtained, and provided by experts.

\subsection{Marketing system}

The marketing system that has been carried out by the respondents so far is selling directly to collectors ( $60 \%$ of the respondents), the middleman $(20 \%$ of the respondents), and the market (20\% of the respondents) (see Figure 5). Based on these data, the marketing carried out by the respondents is a lways done directly (through the offline system). The changes in the marketing system model occurred due to the pandemic situation. Based on the survey results, there was a change; as many as $20 \%$ of the respondents switched to the digital marketing system (the online system). The online marketing system reduces the amount of direct marketing to the collectors due to the inability of the collectors to collect the harvest. Harvests that were not well distributed due to regional restrictions during the pandemic limit the space for collectors to send harvests in large qua ntities. Distribution restrictions have caused collectors to not be able to accommodate all harvest and products. This has forced farmers and aquaculturists to market their crops independently. One way to do this is using online social media. This opens the opportunity in that there is an interest from the farmers and a quaculturists to market their harvests online. For this rea son, educating farmers and fish farmers conceming the marketing system can be carried out in order to support equitable distribution of the harvest to maintain the stability of the products' prices.

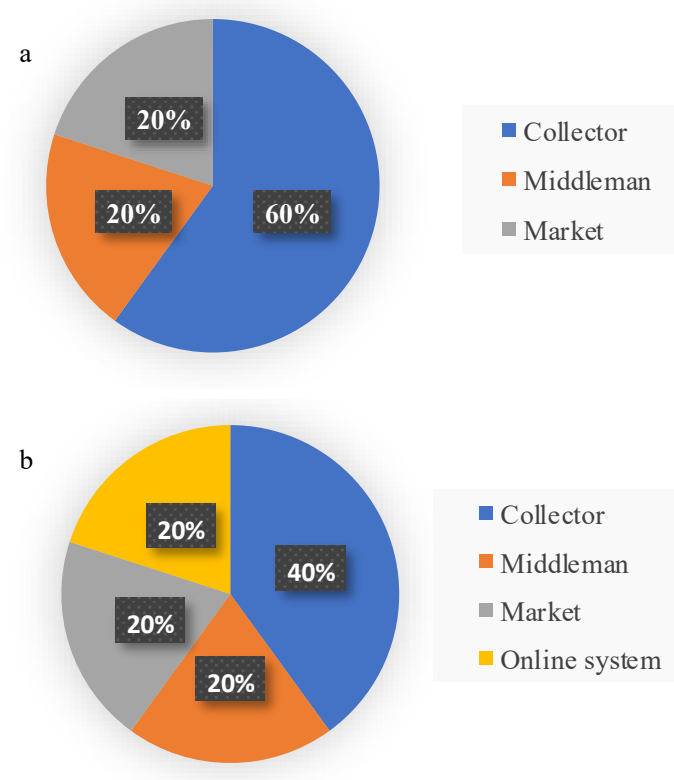

Figure 5. marketing system that is carried out on the situation, a) before; b) during a pandemic 

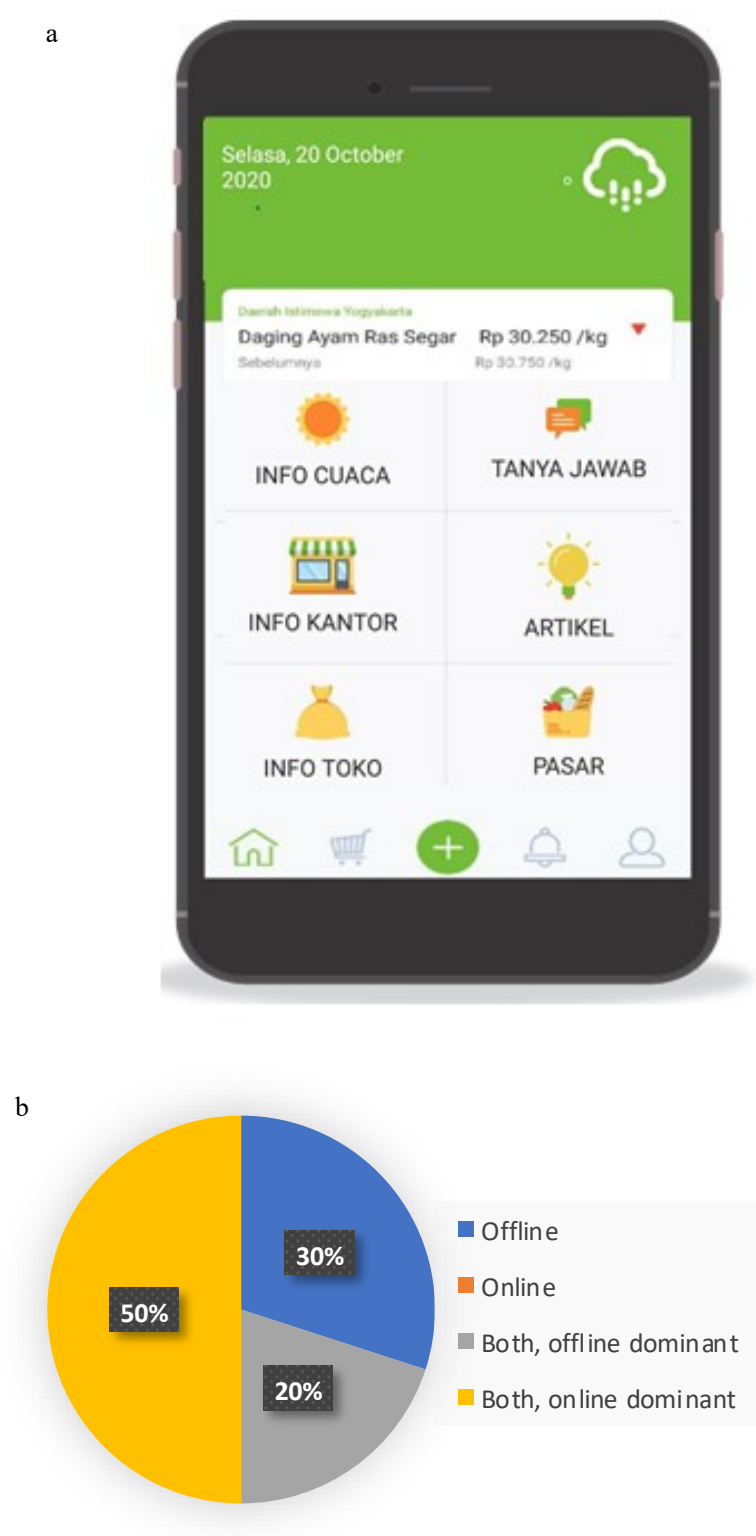

Figure 6. a) Menu display on the desa apps application; b) expected marketing system by respondents

Increased awaren ess of farmers and aquaculturists that there are online marketing opportunities is shown in Figure 6.b; as many as $70 \%$ of the respondents want to utilize an online marketing system. The development of the existing PASAR features in Desa Apps (Figure 6.a) needs to be maximized to support distribution and marketing done by the farmers and aquaculturists.

\section{CONCLUSION}

The digitization of information systems and marketing of the a grocomplex sector provides a great opportunity for maintaining food security in terms of production and distributions. The challenge is educating farmers and aquaculturists on how to use information and communication technology, especially digital product marketing. Although the majority of farmers and aquaculturists have obtained information online, the truth or validity of the information obtained needs to be evaluated by confirming it with experts in the fields. The Desa Apps provides a great opportunity for maintaining its existenceand making innovations as an official and a trusted platform that is expected to provide market education and information to farmers and a quaculturists.

\section{ACKNOWLEDGEMENT}

The authors would like to thank the Directorate of Research Universitas Gadjah Mada for the funding the Faculty of Agriculture and Faculty of Agricultural Technology for its support and facilities, community enga gement partners, and all those who had helped the a uthors execute these activities. The authors would also like to thank the assisted farmer group for their contribution and involvement during these activities

\section{REFERENCES}

Anonim. (2016). UGM Luncurkan Desa Apps Dan UGM Mall di Dies Natalis Ke-67. https://www.gamatechno.com/news/ugmluncurkan-desa-apps-dan-ugm-mall-di-diesna talis-ke-67/

Ba dan Koordinasi Penanaman Modal. (2020)

Subejo, Wati, R.I., Kriska, M, Akhda, N.M., Kristian, A.I., Wimatsari, A.D., Pengga lih, P.M., (2018). Akses, Penggunaan Dan Faktor Penentu Pemanfaatan Teknologi Informasi Dan Komunikasi Pa da Kawasan Pertanian Komersial Untuk Mendukung Ketahanan Pangan Di Perdesaan Yogyakarta. Jurnal Ketahanan Nasional. $\quad 24$ https://doi.org/10.22146/jkn.30270

Susanne Schwarzl and Monika Grabowska. (2015). "Online marketing strategies: the future is here", Journal of International Studies, 8 (2), 187-196.

Supriyanto, B. (2020). Dampak Pandemi Covid-19, Ekonomi Indonesia Diperkirakan Pulih 2022. https://ekonomi.bisnis.com/

Raya, A.B., Wastutiningsih, S.P., Penggalih, P.M., Sari, S.P., Purwani, D.A. (2017). Tantangan Literasi Informasi Petani Di Era Informasi: Studi Kasus Petani di Lahan Pasir Pantai Da erah Istimewa Yogya karta. JSEP, 10 (1)

Raya, A. B., Kriska M., Wastutiningsih, S.P., Cahayaningtyas, M.U., Djitman A., Cahyani G.F. (2018). Strategi Pemanfaatan Aplikasi Desa Apps da lam Literasi Informasi Pertanian. Jurnal Komunikasi Pembangunan., 16 (2).

Ridhoi, M.A. (2020). "Pasokan Pangan Dunia Terguncang Covid-19, Bagaimana di Indonesia?" https://katadata.co.id/berita/ 